Sujono dkk.Pendampingan Pengolahan Limbah Ternak.

\title{
Pendampingan Pengolahan Limbah Ternak Sebagai Sumber Energi (Biogas) Menuju Usaha Peternakan Berwawasan Lingkungan Pada Kelompok Ternak Sapi Perah Desa Beji Kec. Junrejo Kota Batu
}

\author{
Dr. drh. Lili Zalizar, M. S. ${ }^{1)}$ \\ Prof. Dr. Sujono, M. Kes. . ${ }^{2)}$ \\ Ir. Ahmad Yani, M. P. 3)
}

\section{Ringkasan}

Dusun Karangjambe Desa Beji terdapat 250 KK, 50 KK diantaranya memiliki 153 sapi perah, umumnya lokasi kandang berdampingan dengan rumah sedangkan limbah ternak dibiarkan menumpuk di dekat kandang dan dibuang ke sungai yang kemudian mencemari lingkungan berdampak pada kerusakan lingkungan.

Limbah ternak yang dihasilkan di dusun Karangjambe desa Beji sekitar 1,5 ton/ hari dari 153 sapi perah merupakan potensi biogas dan pupuk organik yang besar. Pemanfaatan limbah tersebut dapat terwujud dengan memberikan pendampingan cara pengolahan limbah ternak kepada peternak yang selama ini belum banyak memperoleh pengetahuan dan pengalaman untuk itu.

Pendampingan ini dilkukan selama 6 bulan dengan beberapa tahapan. Tahapan pertama berupa sosialisasi dan pengenalan teknologi pengolahan limbah. Tahap kedua pelatihan dan pendampingan perancangan serta perakitan instalasi biogas. Tahap ketiga uji coba dan pendampingan penggunaan instalasi biogas dan pupuk organik.

Output dari hasil pendampingan ini adalah telah dibuat 3 unit biogas untuk 3 rumah tangga peternak yang telah beroperasi dengan baik dan telah dihasilkan pupuk organik 150 kg/hari. Peternak di desa Beji telah menyadari pentingnya pengolahan limbah ternak dikarenakan dapat menghasilkan pupuk organik, biogas, dan lingkungan sekitar ternak juga kandang menjadi lebih bersih, lebih sehat.

Diharapkan dari hasil pendampingan ini, peternak-peternak yang lain akan membuat instalasi biogas dan pupuk organik secara mandiri agar tercipta suatu keuntungan yang berlipat selain lingkungan desa Beji bersih dan sehat ada manfaat dari penggunaan biogas dan penggunaan pupuk organik.

1) 2) 3) Staf Pengajar Fakultas Pertanian-Peternakan UMM 
Jurnal Dedikasi Volume 7, Mei 2010

\section{A. PENDAHULUAN}

\section{Analisis Situasi :}

Visi pembangunan nasional bidang peternakan adalah terwujudnya masyarakat yang sehat dan produktif serta kreatif melalui pembangunan peternakan yang tangguh berbasis sumber daya lokal. Sedangkan misinya adalah menyediakan pangan asal ternak yang cukup, memberdayakan SDM peternakan agar mampu menghasilkan produk yang berdaya saing tinggi, menciptakan peluang ekonomi untuk meningkatkan pendapatan peternak, menciptakan lapangan kerja di bidang agribisnis peternakan serta melestarikan dan memanfaatkan sumber daya alam pendukung peternakan secara optimal serta tidak mencemari lingkungan sekitar.

Salah satu bidang peternakan yang dapat diandalkankan adalah usaha sapi perah. Usaha sapi perah selain dihasilkan susu, juga dapat dimanfaatkan limbahnya untuk sumber energi yang murah dan terbarukan. Limbah sapi perah berupa feces dan urine dianggap sampah yang tidak memiliki nilai apa-apa, dibiarkan dan dibuang sembarangan sehingga menimbulkan penecemaran lingkungan yang berdampak pada tingkat kesehatan lingkungan masyarakat yang rendah.

Usaha sapi perah di desa beji,Kec.junrejo Kota batu sudah sejak berdirinya KUD Batu dan memanfaatkan limbah kulit kedele yang dibuat tempe. Karena sebagian besasr masyarakatnya berusaha home industri tempe. Namun manajemen perkandangan dan limbah ternak di desa Beji ini belum ditangani secara baik, dimana kandang ternak berdampingan dengan rumah dan limbah ternak dibiarkan menumpuk di dekat kandang atau dibuang ke sungai yang mencemari air sungai. Pola penanganan limbah ini berdampak pada kondisi lingkungan penduduk yang kurang sehat karena pencemaran oleh limbah ternak dan bila hal ini dibiarkan dalam jangka panjang maka akan terjadi pencemaran lingkungan yang lebih parah. Kondisi tersebut sangat dimungkinkan mengingat di Dusun Karangjambe Desa Beji dari 250 KK sebanyak $50 \mathrm{KK}$ memelihara sapi perah atau $20 \%$ penduduk memelihara sapi perah (Data Desa Beji, 2008).

Potensi limbah ternak yang sekaligus merupakan potensi biogas di Dusun Karangjambe Desa Beji dari 153 ekor sapi perah sekitar 1,5 ton/hari, dan bila limbah ini dikelola dengan baik melalui biogas justru merupakan sumber energi yang murah dan ramah lingkungan sedangkan hasil limbah dari biogas merupakan pupuk organik yang sangat bermanfaat bagi rekonstruksi lahan/tanah pertanian yang telah mengalami pemiskinan hara akibat penggunaan pupuk kimia dalam jangka panjang. Untuk mewujudkan harapan di atas diperlukan adanya kepedulian dari semua peternak dan peran serta perguruan tinggi dalam memberikan penyuluhan dan pendampingan secara berkelanjutan dalam upaya menciptakan agribisnis sapi perah yang berwawasan lingkungan dengan mengedepankan pengelolaan limbah secara konsisten.

Kebutuhan bahan bakar bagi penduduk berpendapatan rendah maupun miskin, terutama di pedesaan, sebagian 
Sujono dkk.Pendampingan Pengolahan Limbah Ternak.

besar dipenuhi oleh minyak tanah yang memang dirasakan terjangkau karena disubsidi oleh pemerintah. Namun karena digunakan untuk industri atau usaha lainnya, kadang-kadang terjadi kelangkaan persediaan minyak tanah di pasar. Selain itu mereka yang tinggal di dekat kawasan hutan berusaha mencari kayu bakar, baik dari ranting-ranting kering dan tidak jarang pula menebangi pohon-pohon di hutan yang terlarang untuk ditebangi, sehingga lambat laun mengancam kelestarian alam di sekitar kawasan hutan.

Energi terbarukan lain yang dapat dihasilkan dengan teknologi tepat guna yang relatif lebih sederhana dan sesuai untuk daerah pedesaan adalah energi biogas dengan memproses limbah bio atau bio massa di dalam alat kedap udara yang disebut digester. Biomassa berupa limbah dapat berupa kotoran ternak bahkan tinja manusia, sisa-sisa panenan seperti jerami, sekam dan daun-daunan sortiran sayur dan sebagainya. Namun, sebagian besar terdiri atas kotoran ternak.

Tim pelaksana sudah berpengalaman dalam pembuatan instalasi biogas yang murah dan mudah dipraktekkan. Sehingga melalui pendampingan yang dilaksanakan oleh tim kepada peternak memiliki peran yang strategis untuk ikut membantu mengatasi permasalahan limbah ternak dimanfaatkan sebagai sumber energi untuk memasak kedele sebelum diolah menjadi tempe bagi masyarakat Desa beji menjadi alternatif ketika masyarakat dihadapkan oleh tingginya harga BBM (minyak tanah) dan dunia mengalami krisis energi.
2. Idenfikasi dan Perumusan Masalah : Berdasarkan uraian latar belakang di atas dapat dirumuskan permasalahan sebagai berikut :

1. Limbah ternak sapi perah di desa Beji Junrejo masih dianggap sampah dengan model pengelolaan ditumpuk sekitar lokasi kandang/rumah atau dibuag ke kali.

2. Kurangnya pengetahuan dan kesadaran peternak bahwa pengelolaan limbah secara konvensional di atas berdampak pada pencemaran lingkungan dan kesehatan masyarakat serta dapat menurunkan kualitas susu.

3. Peternak belum memanfaatkan limbah ternak sebagai sumber energi alternatif melalui biogas maupun sebagai pupuk organik walaupun sudah dilaksanakan penyuluhan dan pendampingan dari Perguruan Tinggi.

4. Peternak masih beranggapan bahwa instalasi biogas itu mahal dan rumit dalam pembangunannya.

\section{Tujuan Kegiatan}

Berdasarkan uraian perumusan masalah di atas maka capaian yang menjadi tujuan/target program pengabdian ini adalah melalui model pendampingan di kelompok peternak sapi perah Desa Beji Junrejo adalah :
1. Menumbuhkan kesadaran peternak bahwa limbah ternak 
sapi perah perlu dikelola secara bertanggungjawab.

2. Meningkatkan pengetahuan dan kesadaran peternak bahwa pengelolaan limbah secara konvensional berdampak pada pencemaran lingkungan dan kesehatan masyarakat serta dapat menurunkan kualitas susu.

3. Memotivasi peternak memanfaatkan limbah ternak sebagai sumber energi alternatif melalui biogas maupun sebagai pupuk organik melalui penyuluhan, demonstrasi dan pendampingan.

4. Meyakinkan peternak bahwa instalasi biogas itu murah, sederhana dan ekonomis.

\section{Kerangka Pemecahan Masalah}

Permasalahan utama yang dihadapi oleh kelompok peternak Sapi Perah Desa Beji Junrejo adalah limbah ternak yang mencemari lingkungan dan sungai, kurangnya pengetahuan dan ketrampilan dalam penngelolaan limbah, kesehatan ternak kurang diperhatikan. Oleh karena itu usulan pemecahan masalah sebagai berikut:

1. Memberikan pendidikan dan penyuluhan tentang pentingnya pengelolaan limbah ternak secara bertanggungjawab, pemanfaatan limbah pertanian untuk sumber energi (biogas) dan pupuk organik.

2. Melakukan pendampingan kepada kelompok peternak dalam pembuatan instalasi biogas, teknik dan cara pengisian slurry, pemanfaatan limbah bidigester sebagai pupuk organik serta cara perawatan instalasi biogas.

3. Memberikan informasi terbaru tentang perkembangan kelompok dan usaha ternak perah yang telah maju dalam pengelolaan limbah baik biogas, pupuk organik maupun yang lainnya.

\section{Sasaran Kegiatan}

Adapun kelompok sasaran Program Pengabdian yaitu sekitar 20 orang peternak sapi perah yang tergabung dalam KUD Batu yang berlokasi di Desa Beji Kecamatan Junrejo Kota Batu.

\section{Metode Kegiatan}

Untuk pemecahan permasalahan yang dihadapi kelompok peternak sapi perah Desa Beji Kecamatan Junrejo tercapai tujuan yang telah direncanakan, menggunakan metode sebagai berikut:

1. Metode Ceramah dan Diskusi :

Metode ini dipilih untuk menyampaikan beberapa aspek yang meliputi: Dampak limbah ternak terhadap lingkungan, instalasi biogas, pupuk organik, nilai ekonomis limbah ternak, perawatan biogas, potensi dan permasalahan limbah dalam usaha sapi perah serta usaha dan kegiatan untuk mengatasi permasalahan limbah dalam upaya meningkatkan kesadaran peternak terhadap usaha peternakan berwawasan lingkungan di Desa Beji Junrejo.

2. Metode Demonstrasi

Metode ini digunakan untuk mendemonstrasikan kegiatan-kegiatan yang bersifat aplikatif yang secara langsung 
Sujono dkk.Pendampingan Pengolahan Limbah Ternak.

dapat disaksikan dan dicobakan oleh seluruh anggota kelompok peternak Desa Beji ada suatu tempat yang telah ditentukan. Misalnya: cara membuat instalasi biogas, cara membuat kompor biogas, cara pencampuran kotoran dan air sebelum dimasukkan dalam biodigester. 3. Metode Pendampingan

Setelah peternak menjalani dua tahap diatas dan diyakini memahami dan menguasai apa yang telah dibekali, maka selanjutnya dilakukan pendampingan terhadap kelompok peternak sapi perah dengan mendatangi langsung peternak pada saat mereka melakukan kegiatan operasional pengolahan limbah.

\section{Rancangan Evaluasi}

Rancangan evaluasi terhadap keberhasilan kegiatan pengabdian pada kelompok peternak sapi perah desa Beji secara umum dilakukan dengan berpedoman pada :

1. Keselarasan topik yang dikerjakan dengan keadaan peternak desa Beji.

1. Tingkat partisipasi, sikap dan tanggapan dari peternak terhadap kegiatan yang dilaksanakan dan berusaha menerapkan pengetahuan dan keterampilan yang diperoleh dalam pengolahan limbah sapi perah.

3. Terjadi efisiensi penggunaan biaya energi rumah tangga peternak peternak setelah menerapkan pengetahuan dan keterampilan yang diperoleh kemudian dilakukan evaluasi langsung terhadap tingkat pendapatan sebelum dan sesudah adanya pendampingan.

Adapun Rancangan Evaluasi Secara Rinci di Sajikan pada Tabel 1 Berikut ini.
Tabel 1. Rancangan Eraluasi Program Pengabdian Pada Kelompok Peternak Desa Beil Junrejo.

\begin{tabular}{|c|c|c|c|c|c|}
\hline No & $\begin{array}{l}\text { Anpol y yang did } \\
\text { groluagi }\end{array}$ & What Exaluasi & Kriteria Exoluasi & Indilkator & $\begin{array}{l}\text { Thlol ther } \\
\text { Koherhasilem }\end{array}$ \\
\hline 1. & $\begin{array}{l}\text { Sogialigagi } \\
\text { Kogigam }\end{array}$ & Noret 2009 & $\begin{array}{l}\text { - Jumlah patenal: } \\
\text { yang inut }\end{array}$ & 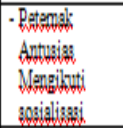 & $\begin{array}{l}\text {-Pasarta } \\
\text { Sosialisai } \\
\text { Labih drai } 25 \\
\text { orang }\end{array}$ \\
\hline 2. & 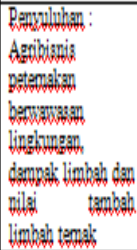 & April sd. Neid 2009 & $\begin{array}{l}\text { - Jumlah paserta } \\
\text { paryuluhan, } \\
\text { kesispan penateri } \\
\text { dan respon } \\
\text { paserta }\end{array}$ & $\begin{array}{l}\text { - Pesarta } \\
\text { Pernyluhan } \\
\text { meninglisat dan } \\
\text { datang tepst } \\
\text { waktupemateri } \\
\text { menguasei } \\
\text { materi. }\end{array}$ & $\begin{array}{l}\text { Peserta } \\
\text { program >30 } \\
\text { orang, pensteri } \\
\text { mendspat } \\
\text { geresiasi dari } \\
\text { paserta program }\end{array}$ \\
\hline 3. & 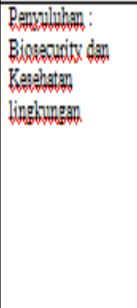 & Appil sd. Nei 2009 & 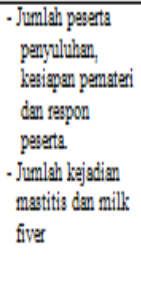 & 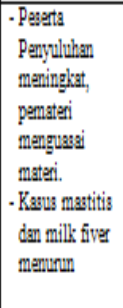 & 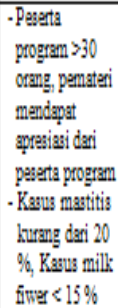 \\
\hline 4. & $\begin{array}{l}\text { Penviluben: } \\
\text { Perlondengen }\end{array}$ & April sd Jng 2009 & $\begin{array}{l}\text { - Konstrulsi, } \\
\text { kemiringan, } \\
\text { ventilasi, sanitasi } \\
\text { dan peralatan } \\
\text { kandang }\end{array}$ & $\begin{array}{l}\text { - Konstulasi, } \\
\text { sanitasi dan } \\
\text { peralatan } \\
\text { kandang } \\
\text { memenuhi } \\
\text { stands }\end{array}$ & 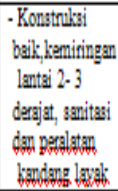 \\
\hline 5. & 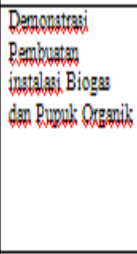 & Mei sd dum 2009 & 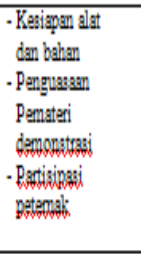 & 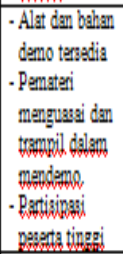 & $\begin{array}{l}\text { - Behan dan alat } \\
\text { demo tersadia } \\
\text { lenglagp } \\
\text { - Petenal: } \\
\text { Antusias ilut } \\
\text { demo dan } \\
\text { partisipasinya } \\
\text { tingei. }\end{array}$ \\
\hline 6. & 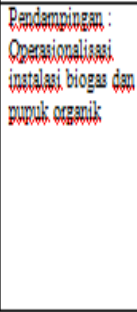 & Jund and 2009 & $\begin{array}{l}\text { - Peraratan } \\
\text { Instalasi } \\
\text { - Keberhasilan } \\
\text { Biogas dan pupul: }\end{array}$ & 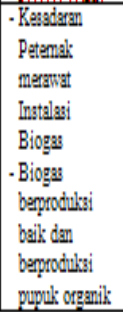 & 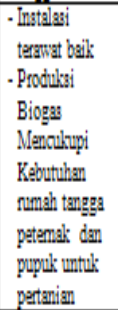 \\
\hline
\end{tabular}


Jurnal Dedikasi Volume 7, Mei 2010

\section{B. Tahap Persiapan dan Perencanaan} Sebelum pelaksanaan

pendampingan dalam bentuk kegiatan penyuluhan dan demonstrasi pembuatan biogas sebanyak 3 unit pada kelompok peternak dilakukan, maka pada awal bulan Maret 2009 dilakukan survey lokasi oleh Tim Pengabdian Masyarakat yang berjumlah 4 orang, untuk mencari lokasi yang tepat sekaligus menjalin komunikasi awal dengan anggota kelompok yang bergabung di kelompok "Peternak Dusun Karangjambe Desa Beji”. Dari hasil pertemuan awal dan survey oleh Tim Pengabdian Masyarakat, maka terdapat beberapa hal yang harus disiapkan terlebih dahulu sebelum pelaksanaan di lapangan dilakukan.

Adapun hal-hal yang harus dipersiapkan oleh Tim pendampingan antara lain:

1. Materi penyuluhan yang meliputi : a) Agribisnis peternakan berwawasan lingkungan, dampak limbah dan nilai tambah limbah ternak b) Biosecurity dan kesehatan lingkungan c) Pembuatan instalasi biogas dan pupuk organik d) operasionalisasi biogas dan pupuk organik.

2. Bahan penyuluhan dan pelatihan tersebut disediakan oleh Tim Pengabdian Masyarakat, sedangkan penggalian lubang digester dan saluran pembuangan dikerjakan oleh peternak. Untuk pelatihan perakitan instalasi biogas mulai dari pemasangan pipa, pembuatan bak pencampuran slurry hingga pembuatan kompor melibatkan peternak semaksimal mungkin sehingga terjadi alih teknologi.

3. Merancang pertemuan rutin kelompok dan pertemuan lapang, pertemuan kelompok minimal 1 kali 2 minggu. Isi kegiatan meliputi acara diskusi kelompok secara rutin setelah penyuluhan dan pelatihan dilaksanakan. Pertemuan lapang diisi dengan kegiatan praktek perakitan instalasi biogas dan praktek mengoperasikan instalasi

biogas.

\section{Pelaksanaan Pendampingan}

1. Agribisnis peternakan berwawasan lingkungan, dampak limbah dan nilai tambah limbah ternak

Kegiatan penyuluhan ini dilaksanakan dengan metode ceramah dan diskusi. Metode ini dipilih untuk menyampaikan pengenalan tentang usaha peternakan berwawasan lingkungan dengan mengembangkan konsep bahwa usaha peternakan sapi perah dapat dilakukan dengan tetap mengkondisikan lingkungan tetap lestari. Hal tersebut dapat dicapai dengan mengendalikan semaksimal mungkin dampak dari limbah ternak seperti sisa pakan, kotoran ternak dan air kencing ternak untuk tidak dibuang secara bebas ke lingkungan sekitar yang dapat menimbulkan pencemaran lingkungan. Langkah yang dapat ditempuh untuk mengendalikan sekaligus mengolah limbah untuk memberikan nilai tambah bagi rumah tangga peternak adalah dengan membuat biogas dan pupuk organik. 
Sujono dkk.Pendampingan Pengolahan Limbah Ternak.

Materi penyuluhan : Agribisnis peternakan berwawasan lingkungan, dampak limbah dan nilai tambah limbah ternak ini disajikan secara bergantian oleh Prof. Dr. Sujono dan Ir. Ahmad Yani, M.P. Di akhir sesi penyuluhan ini diadakan diskusi dan timbul beberapa pertanyaan yang dengan tangkas dijawab oleh kedua pemateri. Pertanyaan antara lain adalah : Masyarakat belum tahun bahwa kotoran yang keluar dari digester dapat langsung digunakan sebagai pupuk.

Instalasi biogas dapat dibuat dengan biaya yang murah dengan bahanbahan yang murah seperti dari plastik polyeteline terutama untuk skala kecil (Amaru, 2004). Disamping itu teknologi biogas sangat sederhana dapat dikuasai oleh peternak dengan mudah dalam waktu yang singkat (Anonim, 2005).

\section{Biosecurity dan kesehatan lingkungan}

Materi penyuluhan Biosecurity dan Kesehatan Lingkungan disajikan oleh Dr. Lili Zalizar, M.S. yang didampingi oleh Ir. Suyatno, M.Si. Pemateri mengupuas tuntas tentang pentingnya kebersihan kandang, kebersihan lingkungan kandang, kebersihan ternak dan peternak dalam usaha peternakan sapi perah untuk mencegah mewabahnya berbagai macam penyakit ternak. Disarakan kepada peternak untuk menyemprot ternaknya secara rutin 1 kali 2 minggu dengan bahanbahan antiseptik seperti rodalon dan selalu waspada dengan orang lain yang masuk kandang artinya perlu pembatasan orangorang untuk masuk lokasi kandang. Materi yang juga disampaikan antara lain tentang berbagai penyakit pada sapi perah seperti mastitis, perut kembung, ketosis, kelumpuhan dan lain-lain yang dapat meyebabkan produksi susu menurun dan tidak dapat dijual. Setelah ceramah selesai dilanjutkan dengan diskusi.

Pelaksanaan diskusi pada sesi ini berlangsung dengan penuh antusis oleh peternak. Permasalahan yang sering muncul ditanyakan adalah sekitar mastitis dan kembung yang kemudian dijawab oleh pemateri Dr. Lili Zalizar, M.Si. Kejadian masititis lebih diakibatkan oleh manajemen perkandangan yang kurang baik, sanitasi yang buruk dan sistem pemerahan yang tidak professional. Hal tersebut dapat diatasi dengan penanganan manajemen usaha peternakan yang mengedepankan sanitasi yang baik. Selain itu pemateri menjelaskan bahwa apabila ternak terkena penyakit kembung, maka dapat diberikan obat tradisional berupa: 1) Daun sembukan, 2) Campuran daun sembung, minyak kayu putih dan air hangat, 3) campuran minyak kelapa, minyak kayu putih, garam, dan air hangat.

\section{Pembuatan Instalasi Biogas dan Pupuk Organik.}

Materi penyuluhan tentang pembuatan instalasi biogas ini merupakan materi inti yang terkait langsung dengan pengolahan limbah ternak oleh karena itu pemateri telah mengiapkan materi yang lengkap mulai dari teknis perhitungan alat dan bahan yang diperlukan, biaya pembelian alat dan bahan, cara membuat lubang digester yang bebar, bak pencampur slury, saluran pembuangan, cara menangkap gas bio ingá teknis pembuatan kompor biogas dari kaleng-kaleng limbah dari pesticida nimia maupun limbah bedak bayi. Materi ini disampaikan secara 
bergantian oleh Ir. Suyatno, M.Si, dan Ir. Ahmad Yani, MP.

Ringkasan pokok-pokok materi yang disampaikan pada penyuluhan ini adalah :

1. Pengertian biogas

2. Teknologi biogas

3. Alat Pembangkit biogas (Slurry)

4. Infrastruktur pembangkit biogas

5. Proses pemcampuran kotoran ternak yang meliputi kegiatan : filtrasi pertama (penyaringan kotoran ternak pertama), pencampuran air dengan kotoran ternak, filtrasi kedua, pemasukan campuran kedalam parit pembangkit.

6. Pemanfaatan limbah biogas sebagai pupuk organik cair maupun padat.

(Pound et.al., 1981)

Adapun jawaban dari Tim Pengabdian dari beberapa pertanyanaan yang diajukan oleh peternak adalah sebagai berikut :

1. Fungsi penyaringan kotoran ternak adalah agar tidak tercampur dengan bahan-bahan lain seperti kayu, ranting, jerami yang kasar sehingga dapat merobek instalasi biogas dari plastik baik pada penyaringan pertama maupun kedua..

2. Gas metan akan mulai dihasilkan pada minggu I setelah pengisian slurry namun baru mulai menghasilkan nyala api apabila tabung penampung gas sudah penuh sekitar 4 minggu sejak pengisian slurry.
3. Pupuk yang keluar dari biogas dapat langsung digunakan pada tanaman dan tidak menimbulkan kematian pada tanaman, sebab gas metan yang dapat mematikan tanaman telah ditangkap pada tabung penambung gas yang selanjutnya digunakan sebagai sumber energi kompor biogas. Pupuk organik dari biogas sangat aman bagi tanaman serta cocok untuk tanaman sayur-sayuran. Pupuk ini sangat ekonomis dan menguntungkan petani sayur maupun petani tanaman yang lainnya.

4. Pupuk dari biogas tidak perlu diolah lebih lanjut lagi karena sudah dalam bentuk pupuk siap pakai. Namun bila peternak ingin membuat dalam bentuk pupuk cair maupun pupuk padat tinggal memisahkan antara bagian cair dikemas cair menjadi pupuk cair sedangkan bentuk padat dikeringk matahari terlebih dahulu lalu dikemas menjadi pupuk organik padat.

Penyuluhan ini berlangsung hingga tengah malam karena banyaknya pertanyaan dari peserta, namun tetap dihentikan karena akan ditindak lanjuti dengan program pembuatan biogas sebanyak 3 unit yang dapat diikuti oleh seluruh peternak di desa Beji.

Biogas merupakan bahan bakar alternatif asal ternak yang saat ini cukup diminati oleh peternak sapi baik skala besar maupun skala kecil, disamping itu limbah biogas (slury) dapat digunakan 
langsung serbagai pupuk organik (Syamsuddin dan Iskandar, 2005) dan (Burhani, 2008).

\section{Operasionalisasi Biogas dan Pupuk Organik}

Materi ini disajikan dengan metode ceramah dan diskusi. Peternak sangat antusias mengikuti materi ini, karena secara teori peternak telah memperoleh cara bagaimana membuat instalasi biogas dan memanfaatkan pupuk dari biogas. Operasionalisasi biogas dilakukan dengan cara : cara membersihkan kotoran ternak dari benda asing yang dapat membahayakan keamanan instalasi biogas, mencampur air dengan kotoran ternak dengan perbandingan 1 : 1 . lalu diaduk sampai homogen kemudian dimasukkan dalam tanki penampung (biodigester). Pengisian ini dilakukan pagi dan sore hari secara terus menerus. Semua kran dalam kondisi off ketika tidak digunakan biogas yang diproduksi. Ketika biogas digunakan, kran yang menuju ke kompor dibuka lalu kompornya dikorek dengan korek api sehingga akan muncul api dengan warna biru lalu kita dapat memasak sesuai kehendak kita.

Penyuluhan ini berlangsung dalam suasana dimana peternak sedang menghadapi kesulitan dengan gas elpiji dan minyak tanah. Oleh karena itu adanya bantuan 3 unit Instalasi biogas yang ditempatkan pada : Bapak Kukuk, Bapak Suraji dan Bapak Sunarto merupakan salah peran Perguruan Tinggi dalam ikut meringankan beban hidup masyarakat dalam hal energi.
Pupuk organik dari biogas dapat secara langsung dapat digunakan untuk rumput, padi, jagung, mapun tanaman sayur-sayuran. Berdasarkan pengalaman pada petani sayur didesa Sidomulyo Batu, bahwa pupuk organik dari ternak sangat cocok untuk digunakana pada tanaman sayur-sayuran dan bunga serta buah-buahan karena menghasilkan sayur, buah dan bunga yang berkualitas tinggi dan produksinya meningkat.

Operasionalisasi biogas di Indonesia masih dilakukan secara sederhana terutama pada peternak-peternak skala kecil karena inovasi teknologi bisa dianggap baru (Anonim, 2008). Lain halnya dengan di China, pemanfaatan energi biogas tidak saja menggunakan limbah ternak tetapi telah merambah pada pemanfaatan tinja manusia sebagai energi alternatif rumah tangga dengan pola operasionalisasi yang lebih maju (Buren A.V., 2001).

\section{Pembuatan Instalasi Biogas.}

Pembuatan instalasi biogas pada 3 peternak yang telah disepakati dilaksanakan secara rutin setiap hari minggu selama 6 minggu yang dilaksanakan secara bergantian oleh Tim Pengabdian. Pada saat ini ketika instalasi biogas tersebut telah berfungsi dan dimanfaatkan oleh peternak untuk kebutuhan rumah tangga dan memanaskan air minum sapi perahnya. Namun demikinan dalam proses pendampingan secara berkelanjutan karena seringkali timbul persoalan terutama produksigas yang tidak stabil karena peternak tidak disiplin mengisi slurry secara rutin. Oleha 
Jurnal Dedikasi Volume 7, Mei 2010

karena itu, dalam menghadapi adanya gangguan pada instalasi biogas yang telah

ada, Tim Pengabdian masih terus memantau perkembangan Biogas yang telah beroperasi.

Hal utama yang harus diperhatikan dalam pemanfaatan instalasi biogas sederhana dari bahan plastik ini adalah menjaga dari gangguan yang dapat menyebabkan plastik teresebut bocor. Pengenalan dan pengembangan teknologi biogas sebenarnya telah lama dilakukan di Asia, namun penyerapan teknologi dari masing-masing negara tidak sama tergantung dari SDM dan kebutuhan akan energi teresebut (Botero dan Preston, 1987) dan (David, 1995).

\section{Kesimpulan dan Saran}

\section{Kesimpulan}

- "Kelompok Peternak Sapi Perah" yang berlokasi di Desa Beji Kecamatan Junrejo Kota Batu merupakan kelompok peternak sapi perah yang memiliki potensi yang besar untuk dikembangkan dan diberdayakan, karena walaupun peternak sudah memahami seluk beluk usaha peternakan, namun masih ditemukan beberapa hal yang perlu untuk dibenahi lebih lanjut.

- Penyuluhan dan pelatihan dalam usaha sapi perah di Desa Beji sangat dinantikan oleh peternak dan dengan kesadaran yang tinggi mereka berharap untuk dilaksanakan secara berkelanjutan.

- Bantuan Instalasi Biogas dan sistem pengolahan pupuk organik hasil Pengabdian Masyarakat pada periode ini telah memberikan nilai tambah yang besar bagi penghematan energi rumah tangga dan penyediaan pupuk organik yang ekonomis.

- Kelompok peternak desa Beji sangat sadar bahwa kegiatan ini akan memberikan dampak ekonomi bagi pendapatan peternak sehingga terbangun motivasi tinggi untuk meneruskan kegiatan usaha sapi perah sebagai tumpuan pendapatan yang menjanjikan.

\section{Saran}

Perlu dilaksanakan pendampingan lebih lanjut pada kelompok peternak yang telah dibina hingga kelompok tersebut betulbetul telah mampu mandiri dalam alih teknologi tepat guna.

\section{DAFTAR PUSTAKA}

Amaru K., 2004, Rancang Bangun dan Uji Kinerja Biodigester Plastik Polyethilene

Skala Kecil (Studi Kasus Ds. Cidatar Kec. Cisurupan, Kab. garut), Tugas

Akhir, Fakultas Pertanian, UNPAD, Indonesia.

Anonim, 2005. Teknologi Biogas. Berita

Kompas. Jakarta. 
Anonim, 2008. Laporan KKN-PPM.

Lembaga Pengabdian

Masyarakat Universitas

Muhammadiyah Malang.

Ariane van Buren, 2001. Chinesse

Biogas Manual.. Intermediate

Technology. London.

Botero dan Preston (1987). Livestock House and Biogas System. FAO.

Bui Xuan An et al 1994). How To Install Polyethylene Biogas Plant. The Royal Agricultural College Cirencester.

Burhani R., 2008. Biogas Sumber Energi Alternatif. Berita Kompas.

David House, 1995. The Biogas

Handbook.. Peace Press.

FAO (1981, The Development and Use of Biogas Technology in Rural Asia.

Khan 1996). Biogas/Biofertilizer Business Handbook Manual. Michael Arnott. Peace Corps.

Pound et al (1981). Biodigester Installation Manual, Lylian rodriguez and $\mathrm{T} \mathrm{R}$ Preston. FAO.

Syamsudin, T.R. dan Iskandar, H.H., 2005, Bahan Bakar Alternatif Asal Ternak,

Sinar Tani, Edisi 21.27 Desember 2005, No. 3129 Tahun XXXVI.

\section{Lampiran}

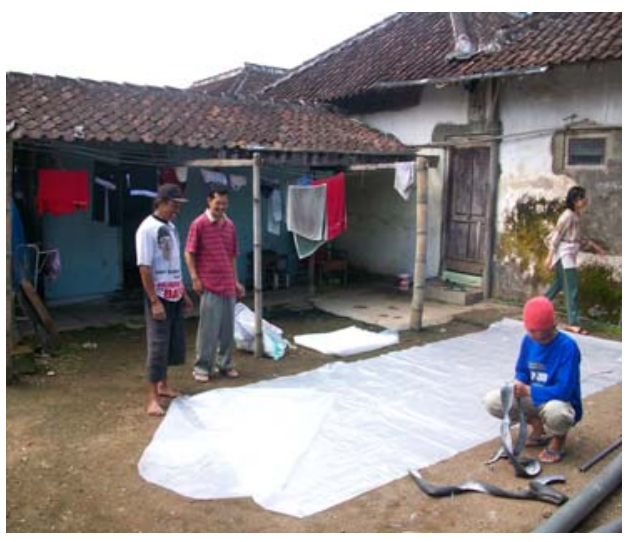

Persiapan Pipa dan Plastik Digester sebelum Dipasang

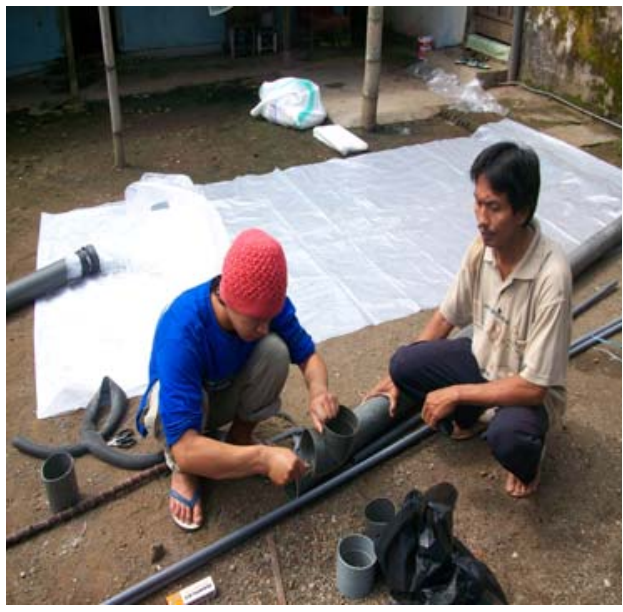

Pengerjaan Penyambungan Instalasi

Biogas 


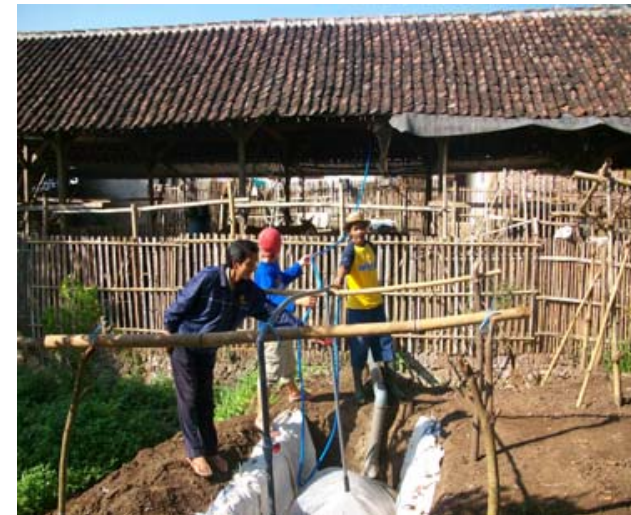

Instalasi Biogas Telah Terpasang dan dalam Proses Pengisisan Slurry

Sambil menunggu Produksi Biogas

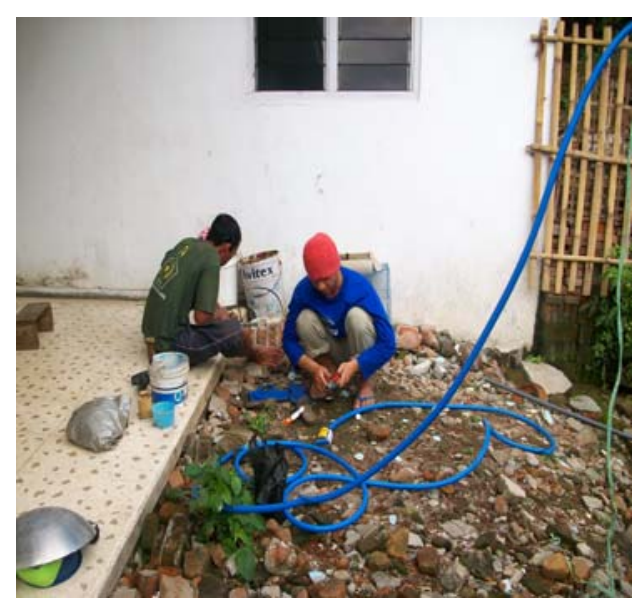

Pembuatan Kompor Gas dari Kaleng Bekas

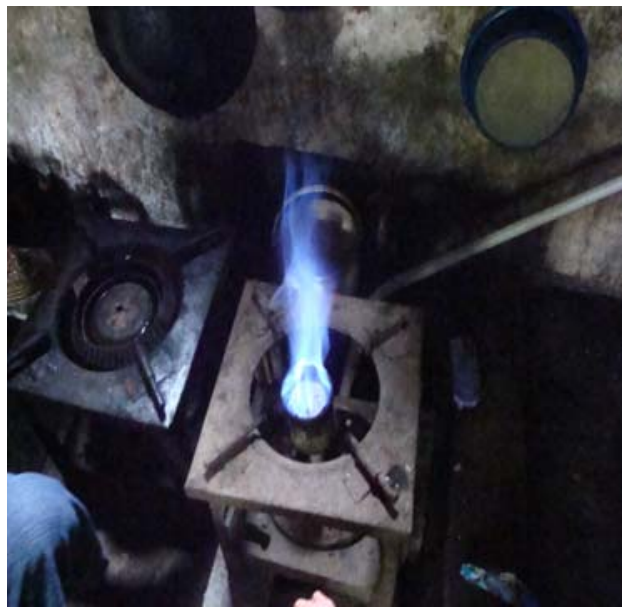

Kompor Biogas Telah Menyala Membara Setelah 4 Minggu

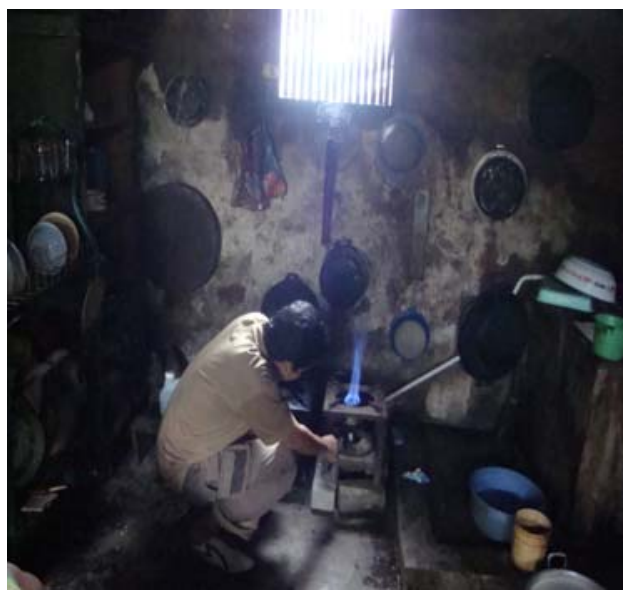

Peternak Sedang Menyalakan Kompor

Biogas di Rumahnya 
Sujono dkk.Pendampingan Pengolahan Limbah Ternak. 